\title{
Comparison of efficacy of 600 and 800 micrograms vaginal misoprostol in early pregnancy failure in SMGS: a tertiary health care hospital in Jammu, India
}

\author{
Reema Khajuria, Arushi Suri, Rohini Jaggi*
}

Department of Obstetrics and Gynaecology, SMGS, GMC, Jammu, Jammu and Kashmir, India

Received: 15 December 2021

Accepted: 03 January 2022

*Correspondence:

Dr. Rohini Jaggi,

E-mail: rohiniabhishekanand@gmail.com

Copyright: (c) the author(s), publisher and licensee Medip Academy. This is an open-access article distributed under the terms of the Creative Commons Attribution Non-Commercial License, which permits unrestricted non-commercial use, distribution, and reproduction in any medium, provided the original work is properly cited.

\begin{abstract}
Background: Misoprostol use in early pregnancy failure is varied and dose is not well established. Aim of this study was to compare efficacy and side effects of 600 versus 800 micrograms vaginal misoprostol in early pregnancy failure. Methods: A randomized prospective observational study was conducted in the postgraduate department of obstetrics and gynaecology, SMGS hospital Jammu from November 2018 to October 2019 after getting approval from the ethical committee. Hundred patients (50 in group A and 50 in group B) admitted in labour room before 12 weeks of gestation with an ultrasound diagnosis of early fetal demise (missed abortion or brightened ovum) were treated medically with different doses of vaginal misoprostol.

Results: The success rate in patients in group A is $72 \%$ and group B is $88 \%, \mathrm{p}=0.045$ (difference is statistically significant). Patients who required suction and evacuation were $28 \%$ in group A and $12 \%$ in group B.

Conclusions: Use of misoprostol for medical management of $1^{\text {st }}$ trimester missed/anembryonic is an effective, cheap, safe and convenient alternative to surgical evacuation. It was concluded that 800 micrograms vaginal misoprostol is more effective than 600 micrograms vaginal misoprostol. But 800 micrograms misoprostol has more side effects than 600 micrograms vaginal misoprostol.
\end{abstract}

Keywords: Misoprostol, Missed abortion, Early pregnancy failure

\section{INTRODUCTION}

Miscarriages are classified into early pregnancy losses (upto 12 weeks of conception) and late pregnancy losses (from $12^{\text {th }}$ to $22^{\text {nd }}$ week of gestation). Approximately 1 in 4 women will experience a miscarriage during her life time. ${ }^{1}$ An increasing proportion of these unsuccessful pregnancies are now diagnosed on routine first trimester ultrasound scanning and designated as missed abortion, which account for approximately $10 \%$ of all first trimester miscarriages. ${ }^{2}$ The standard treatment of both spontaneous and missed abortion used to be surgical evacuation of the uterus but expectant management or medical treatment are becoming reasonable alternatives., ${ }^{3,4}$ The first agent used for medical abortion was mifepristone ${ }^{5}$ initially approved in France in 1988. Misoprostol is a prostaglandin E1 analogue that has been initially used in the prevention of gastric ulcer disease. ${ }^{6}$ In addition, misoprostol has been investigated as an agent to induce abortion. ${ }^{7,8}$ Misoprostol causes cervical ripening. It has been proposed that this action appears to be mainly on the connective tissue stroma with evidence of disintegration and dissolution of collagen. ${ }^{9}$ Misoprostol-a synthetic PGE1 analogue, is cheap, stable at room temperature and effective in inducing cervical ripening and uterine contractions. The most suitable dose of misoprostol for missed abortion is not yet clear. A single dose of $800 \mathrm{mcg}$ of misoprostol by vaginal or oral route was recommended by national institute for health and care excellence. ${ }^{10}$ However, some studies reported a converse opinion, by pointing out that a lower dose or different route may be equally effective. ${ }^{11,12}$ 
The objective of this study is to compare efficacy of 600 and 800 micrograms vaginal misoprostol in early pregnancy failure.

\section{METHODS}

The present study is randomized prospective observational study was conducted in the postgraduate department of obstetrics and gynaecology, SMGS hospital Jammu from November 2018 to October 2019 after getting approval from the ethical committee. A total of 100 patients admitted in labour room with ultrasound diagnosis of early fetal demise (missed abortion or blightened ovum) were included in the study. Patients in group A were given three doses of 600 micrograms vaginal misoprostol 6 hourly and the other 50 were given three doses of 800 micrograms vaginal misoprostol 6 hourly. Evaluation was done 6 hours after the $3^{\text {rd }}$ dose of misoprostol i.e., at 24 hours. If the uterus was felt empty of products on vaginal examination or ultrasonography showed no products of conception, it was considered as treatment success.

\section{RESULTS}

The mean age of patients in group A is 26.2 and in group B is 25.92 years. Primigravida patients in group A were $32 \%$ (16) and in group B were $46 \%$ (23). Patients with one previous vaginal delivery (G2) were $26 \%$ (13) in group A and $22 \%$ (11) in group B. Patients with 2 or more previous vaginal deliveries were $42 \%$ (21) in group A and $32 \%$ (16) in group B. Mean haemoglobin level of patients in group A was $9.46 \mathrm{gm} / \mathrm{dl}$ and in group B was $9.20 \mathrm{gm} / \mathrm{dl}$ (Table 1). All these parameters were not statistically significant.

Table 1: Demographic data of the patients.

\begin{tabular}{|lll|}
\hline Variables & $\begin{array}{l}\text { Group A- } \\
\mathbf{6 0 0} \mathbf{~ m c g}\end{array}$ & $\begin{array}{l}\text { Group B- } \\
\mathbf{8 0 0} \mathbf{~ m c g}\end{array}$ \\
\hline Maternal age (years) & 26.2 & 25.92 \\
\hline Primigravida (\%) & $32(16)$ & $46(23)$ \\
\hline $\begin{array}{l}\text { G2 (1 previous vaginal } \\
\text { delivery) (\%) }\end{array}$ & $26(13)$ & $22(11)$ \\
\hline $\begin{array}{l}\text { G3 or more (2 or more } \\
\text { previous vaginal } \\
\text { deliveries) }(\%)\end{array}$ & $42(21)$ & $32(16)$ \\
\hline Haemoglobin level, (g/d) & 9.46 & 9.20 \\
\hline
\end{tabular}

Mean induction abortion interval was $15.17 \pm 4.96$ hours in group $\mathrm{A}$ and $12.75 \pm 4.12$ hours in group $\mathrm{B}$. The difference was statistically significant $(\mathrm{p}=0.002)$. Induction abortion interval of patients with gestation age 6-8 weeks in group A was $15.08 \pm 4.92$ hours and in group B was $13.29 \pm 3.78$ hours. Induction-abortion interval of patients with gestation age 8-10 weeks in group A was 14.38 \pm 5.04 hours and in group B was $11.63 \pm 4.09$ hours. Induction-abortion interval of patients with gestation age 10-12 weeks was $16.05 \pm 4.92$ hours and in group B was $13.33 \pm 4.42$ hours. Thus, in all gestation age groups, patients who received $800 \mathrm{mcg}$ misoprostol (group B) had shorter inductionabortion interval compared to patients who received 600 mcg vaginal (group B) (Table 2).

Table 2: Gestation age and mean induction-abortion interval.

\begin{tabular}{|c|c|c|c|}
\hline $\begin{array}{l}\text { Gestational } \\
\text { age } \\
\text { (Weeks) }\end{array}$ & $\begin{array}{l}\text { Induction } \\
\text { abortion } \\
\text { interval, } \\
\text { group A-600 } \\
\text { mcg, } \\
\text { (Mean } \pm \text { SD) } \\
\text { (Hours) }\end{array}$ & $\begin{array}{l}\text { Induction } \\
\text { abortion } \\
\text { interval, } \\
\text { group B-800 } \\
\text { mcg, (Mean } \pm \\
\text { SD) (Hours) }\end{array}$ & P value \\
\hline $6-8$ & $15.08 \pm 4.92$ & $13.29 \pm 3.78$ & $0.044(\mathrm{~S})$ \\
\hline 8-10 & $14.38 \pm 5.04$ & $11.63 \pm 4.09$ & $0.003(\mathrm{~S})$ \\
\hline $10-12$ & $16.05 \pm 4.92$ & $13.33 \pm 4.42$ & $0.004(\mathrm{~S})$ \\
\hline Overall & $15.17 \pm 4.96$ & $12.75 \pm 4.12$ & $0.002(\mathrm{~S})$ \\
\hline
\end{tabular}

The induction-abortion interval decreased with increasing parity. In women with gestation age between 6-8 weeks the induction-abortion interval in group A was 16.54 hours for primigravida, 15.50 hours for second gravida and 13.20 hours for third gravida or more and in group B was 13.90 hours for primigravida, 13.58 hours for second gravida and 12.40 hours for third gravida or more. In women with gestation age between 8-10 weeks the induction-abortion interval in group A was 18.64 hours in primigravida, 13.50 hours in second gravida and 11 hours for third gravida or more and in group B was 14.50 hours for primigravida, 10.8 hours for second gravida and 9.6 hours for third gravida or more. In women with gestation age 10-12 weeks the induction-abortion interval in group A was 20.82 hours for primigravida, 14.33 hours in second gravida and 13 hours for third gravida or more and in group B was 16 hours for primigravida, 14 hours for second gravida and 10 hours for gravida 3 or more (Table 3 ).

Table 3: Gravidity and gestation age and induction abortion interval.

\begin{tabular}{|c|c|c|c|c|c|c|}
\hline \multirow[t]{2}{*}{ Gestational age (weeks) } & \multicolumn{3}{|c|}{$\begin{array}{l}\text { Induction abortion interval, group A- } \\
\text { misoprostol } 600 \mathrm{mcg} \text {, (Hours) }\end{array}$} & \multicolumn{3}{|c|}{$\begin{array}{l}\text { Induction abortion interval, group B- } \\
\text { misoprostol } 800 \mathrm{mcg} \text {, (Hours) }\end{array}$} \\
\hline & Primigravida & G2 & G3 and more & Primigravida & G2 & G3 and more \\
\hline $6-8$ & 16.54 & 15.50 & 13.20 & 13.90 & 13.58 & 12.4 \\
\hline 8-10 & 18.64 & 13.50 & 11 & 14.50 & 10.8 & 9.6 \\
\hline $10-12$ & 20.82 & 14.33 & 13 & 16 & 14 & 10 \\
\hline
\end{tabular}


USG was performed 6 hours after $3^{\text {rd }}$ dose. No RPOCs were found in $34 \%$ patients in group $\mathrm{A}$ and $52 \%$ patients in group B. 1-5cc RPOCs were found in $36 \%$ patients in group A and $20 \%$ patients in group B. 5-10 cc RPOCs were found in $2 \%$ patients in group A $8 \%$ patients in group B. $>10 \mathrm{cc}$ RPOCs were found in $28 \%$ patients in group $\mathrm{A}$ and $20 \%$ patients in group B. Hence, greater number of patients in group A had more RPOCs than group B (Table 4).

Table 4: USG after 6 hours of $3^{\text {rd }}$ dose.

\begin{tabular}{|c|c|c|c|}
\hline $\begin{array}{l}\text { USG after } \\
6 \text { hrs of } \\
3^{\text {rd }} \text { dose } \\
\text { (CC) }\end{array}$ & $\begin{array}{l}\text { No. of } \\
\text { patients in } \\
\text { group A-600 } \\
\text { mcg }(\%)\end{array}$ & $\begin{array}{l}\text { No. of } \\
\text { patients in } \\
\text { group B-800 } \\
\text { mcg }(\%)\end{array}$ & $\begin{array}{l}\mathbf{P} \\
\text { value }\end{array}$ \\
\hline $\begin{array}{l}\text { No } \\
\text { RPOCs }\end{array}$ & $17(34)$ & $26(52)$ & \multirow{4}{*}{$\begin{array}{l}0.0001 \\
\text { (S) }\end{array}$} \\
\hline $1-5$ & $18(36)$ & $10(20)$ & \\
\hline $5-10$ & $1(2)$ & $4(8)$ & \\
\hline$>10$ & $14(28)$ & $10(20)$ & \\
\hline
\end{tabular}

The percentage of patients who required surgical evacuation after failed medical management was higher for group A (28\%) than for group B (12\%).

Success rate was higher in the 800 micrograms group as compare to 600 micrograms group. In patients with gestation age between 6-8 weeks the success rate in group A is $75 \%$ while in group B is $95.45 \%$. In patients with gestation age between $8-10$ weeks success rate is higher in group B i.e., $81.81 \%$ as compared to group A in which the success rate is $61.65 \%$. Also, in the patients with gestation age between 10-12 weeks the success rate is lower for group A i.e., 76.64\% than group B i.e., 83.33\%. Hence, in all gestation groups 800 micrograms misoprostol is more effective than 600 micrograms misoprostol (Table 5). Also, the overall success rate is higher in group B i.e., $88 \%$ than in group A i.e., $72 \%$.

Table 5: Success rate/gestational age.

\begin{tabular}{|c|c|c|c|}
\hline $\begin{array}{l}\text { Success rate/ } \\
\text { gestational } \\
\text { age (weeks) }\end{array}$ & $\begin{array}{l}\text { Group A, } \\
\text { no. of } \\
\text { patients } \\
(\%)\end{array}$ & $\begin{array}{l}\text { Group B, } \\
\text { no. of } \\
\text { patients } \\
(\%)\end{array}$ & $\begin{array}{l}\mathbf{P} \\
\text { value }\end{array}$ \\
\hline $6-8$ & $15(75)$ & $21(95.45)$ & \multirow{3}{*}{0.023} \\
\hline $8-10$ & $8(61.5)$ & $18(81.81)$ & \\
\hline $10-12$ & $13(76.4)$ & $5(83.33)$ & \\
\hline
\end{tabular}

The occurrence of side effects was significantly higher with 800 micrograms misoprostol as compared to 600 micrograms misoprostol (Table 6). Excessive bleeding was noticed in 4 patients $(8 \%)$ in group A and no such case was reported in group B. Nausea and vomiting occurred in $2 \%$ patients in group A and in $4 \%$ in group B. Pain and cramps was reported in $6 \%$ patients in group $\mathrm{A}$ and in $18 \%$ patients in group B. In our study fever and shivering occurred in $6 \%$ patients in group $\mathrm{A}$ and $14 \%$ patients in group B.
Table 6. Side effects.

\begin{tabular}{|llll|}
\hline $\begin{array}{l}\text { Side } \\
\text { effects }\end{array}$ & $\begin{array}{l}\text { Group A (600 } \\
\text { meg), no. of } \\
\text { patients }(\%)\end{array}$ & $\begin{array}{l}\text { Group B (800 } \\
\text { mcg), no. of } \\
\text { patients }(\%)\end{array}$ & $\begin{array}{l}\text { P } \\
\text { value }\end{array}$ \\
\begin{tabular}{llll|} 
No side \\
effect
\end{tabular} & $39(78)$ & $32(64)$ & \multirow{2}{*}{0.001} \\
\cline { 1 - 2 } $\begin{array}{l}\text { Excessive } \\
\text { bleeding }\end{array}$ & $4(8)$ & $0(0)$ & \\
\hline Nausea & $1(2)$ & $2(4)$ & \\
\hline $\begin{array}{l}\text { Pain and } \\
\text { cramps }\end{array}$ & $3(6)$ & $9(18)$ & \\
\hline $\begin{array}{l}\text { Fever and } \\
\text { shivering }\end{array}$ & $3(6)$ & $7(14)$ & \\
\hline
\end{tabular}

The patients were followed up after 1 week (Table 7). 78\% patients in group A and $94 \%$ patients in group B reported no bleeding per vaginum at the end of 1 week. More patients in group A i.e., 22\% reported spotting as compared to group B in which only $6 \%$ patients reported spotting at the end of 1 week.

Table 7: Follow up after 1 week.

\begin{tabular}{|llll|}
\begin{tabular}{|l} 
Follow up \\
after 1
\end{tabular} & $\begin{array}{l}\text { Group A (600 } \\
\text { meg), no. of } \\
\text { week }\end{array}$ & $\begin{array}{l}\text { Group B (800 } \\
\text { meg), no. of }\end{array}$ & $\begin{array}{l}\text { P } \\
\text { value }\end{array}$ \\
\hline No BPV & $39(78)$ & $47(94)$ & 0.043 \\
Spotting & $11(22)$ & $3(6)$ & $($ S) \\
\hline
\end{tabular}

\section{DISCUSSION}

The induction abortion interval in patients with 6-8 weeks period of gestation in group A is $15.08 \pm 4.92$ hours while in group B is shorter i.e., 13.29 \pm 3.78 hours. In patients with 8-10 weeks period of gestation the induction abortion interval in group A is $14.38 \pm 5.04$ hours while it is shorter in group B i.e., 11.63 \pm 4.09 hours. In patients with 10-12 weeks period of gestation the induction abortion interval is $16.05 \pm 4.92$ hours and again it is shorter in group B i.e., $13.33 \pm 4.42$ hours. Overall, the mean induction abortion interval in group A is $15.17 \pm 4.96$ hours and in group B is $12.75 \pm 4.12$ hours. The difference between the two groups is statistically significant, $p=0.002$. Similar result was found in the study of Srikhao et al in which the induction to abortion time was shorter in the higher dosage group. ${ }^{13}$ The mean time to abortion was significantly shorter in the 800 micrograms group than in the 400 micrograms group, 9 hours and 16 hours respectively with a $p=0.01$. The difference in their study was statistically significant. The induction abortion intervals were least for patients with 810 weeks period of gestation, higher for patients in 6-8 weeks period of gestation and maximum for patients with 10-12 weeks period of gestation in both the groups as mentioned above. These findings do not match with the study done by Hooja et al in which the induction abortion interval decreased with increasing gestation period. ${ }^{14}$ In this study tablet misoprostol 800 micrograms were given 6 hourly for three doses. The induction abortion interval for patients with gestation ages 6-8 weeks, 8-10 weeks and 10- 
12 weeks was $18.84 \pm 2.37$ hours, $18.18 \pm 3.94$ hours and $16.67 \pm 3.26$ hours respectively.

The cases in the study groups were analysed according to the relation between parity and induction abortion interval. In women with gestation age between 6-8 weeks the induction abortion interval in group A was 16.54 hours for primigravida, 15.50 hours for second gravida and 13.20 hours for third gravida or more and in group B was 13.90 hours for primigravida , 13.58 hours for second gravida and 12.40 hours for third gravida or more. In women with gestation age between 8-10 weeks the induction abortion interval in group A was 18.64 hours in primigravida, 13.50 hours in second gravida and 11 hours for third gravida or more and in group B was 14.50 hours for primigravida, 10.8 hours for second gravida and 9.6 hours for gravida third or more. In women with gestation age between 10-12 weeks the induction abortion interval in group A was 20.82 hours for primigravida, 14.33 hours for second gravida and 13 hours for gravida third or more and in group B was 16 hours for primigravida, 14 hours for second gravida and 10 hours for third gravida or more. In both the groups it can be seen that the induction abortion interval decreases with increasing gravidity. The results are similar to the study of Anita et al, conducted on 200 patients with missed abortion up to 12 weeks period of gestation, in which the induction abortion interval decreased with increasing parity. ${ }^{15}$

USG was performed after 6 hours of $3^{\text {rd }}$ dose. No RPOCs were found in $34 \%$ patients in group $\mathrm{A}$ and $52 \%$ patients in group B. $1-5 \mathrm{cc}$ RPOCs were found in $36 \%$ patients in group A and $20 \%$ patients in group B. 5-10 cc RPOCs were found in $2 \%$ patients in group A and $8 \%$ patients in group B. $>10$ cc RPOCs were found in $28 \%$ patients in group A and $20 \%$ patients in group B. Hence, greater number of patients in group A had more RPOCs than group B. 4 patients in group A had excessive bleeding within 24 hours and an emergency suction evacuation was performed. These patients had large amount of RPOCs on per vaginum examination and $\mathrm{S}$ and $\mathrm{E}$ was performed immediately during the episode of excessive bleeding, thus they are included in the $>10$ cc RPOCs group. No similar study which included the amount of RPOCs could be found.

The percentage of patients who required surgical evacuation after failed medical treatment is higher for group A i.e., $28 \%$ than for group B i.e., 12\%. The results are similar to the study of Barcelo et al in which the percentage of women who underwent surgical evacuation after failed medical treatment is higher in 600 micrograms misoprostol group i.e., $12.2 \%$ than in 800 micrograms misoprostol group i.e., $9.4 \% .^{16}$

Patients of all gestation ages had higher success rate in the 800 micrograms group as compared to 600 micrograms group. In patients with gestation age between 6-8 weeks the success rate in group A is $75 \%$ while in group B is $95.45 \%$. In patients with gestation age between $8-10$ weeks again the success rate is higher in the group B i.e., $81.81 \%$ as compared to group $\mathrm{A}$ in which the success rate is
$61.65 \%$. Also, in patients with gestation age between $10-$ 12 weeks the success rate is lower for group A i.e., 76.64\% than group B i.e., $83.33 \%$. Hence it can be seen that in all gestation groups 800 micrograms misoprostol is more effective than 600 micrograms. The difference is statistically significant with a $\mathrm{p}=0.023$. This result is similar to the study of Barcelo et al who used 600 and 800 micrograms vaginal misoprostol intravaginally in 946 women with missed miscarriage $<12$ weeks and found that the rate of complete evacuation in 600 micrograms group was $87.8 \%$ which was less than total rate of complete evacuation in 800 micrograms group which was $90.6 \% .^{16}$

The overall all success in group A is $72 \%$ which is less than the overall success rate in group $\mathrm{B}$ which is $88 \%$. This result is comparable to the study of Kovavisarach et al in which 114 women were randomly assigned into 2 groups of equal sizes and the effectiveness of 600 and 800 micrograms misoprostol intravaginally were compared. ${ }^{17}$ The rate of complete abortion within 24 hours was significantly higher in the group that received $800 \mathrm{mcg}$ of misoprostol (68.4\%) than in the 600 micrograms of misoprostol group $(45.6 \%)$.

The occurrence of side effects was significantly higher with 800 micrograms misoprostol as compared to 600 micrograms misoprostol. Excessive bleeding was noticed in 4 patients $(8 \%)$ in group $A$ and no such case was reported in group B. This is similar to the study of Ayres de Campos et al which reported one such case (1.35\%) of heavy vaginal bleeding requiring emergency surgical evacuation amongst patients who received 600 micrograms vaginal misoprostol for missed abortion. ${ }^{18}$ Nausea and vomiting occurred in $2 \%$ patients in group A and in $4 \%$ in group B. The results are consistent with the study conducted by Thakur et al in which nausea and vomiting was higher in the 800 micrograms group i.e., $26.25 \%$ as compared to 600 micrograms misoprostol group i.e., 5\%. Pain and cramps were reported in $6 \%$ patients in group A and in $18 \%$ patients in group B. Nearly similar results were found in the study of Thakur et al in which $10 \%$ patients in 600 micrograms group had pain and cramps as compared to $50 \%$ women in 800 micrograms misoprostol group thereby meaning that patients taking higher dose of misoprostol suffered from more pain and abdominal cramps. Fever and shivering occurred in $6 \%$ patients in group A and $14 \%$ patients in group B. Results are similar to the study of Thakur et al in which fever and shivering were higher in 800 micrograms group (48.75\%) as compared to 600 micrograms group $(12.5 \%) .{ }^{19}$

The patients were followed up after 1 week. $78 \%$ patients in group A and $94 \%$ patients in group B reported no bleeding per vaginum at the end of 1 week. More patients in group A i.e., $22 \%$ reported spotting as compared to group B in which only $6 \%$ patients reported spotting at the end of 1 week. Thus, total complete abortion rate is higher in group B as compared to group A. This is comparable to the result of Barcelo et al in which at the first follow up which was 1 week after treatment the total rate of complete 
miscarriage was $90.6 \%$ in the 800 -mcg group as compared to the $600-\mathrm{mcg}$ group in which it was $87.8 \%{ }^{16}$

\section{Limitations}

The limitation of the study was the small sample size of the patients and lack of studies comparing the efficacy of 600 and 800 micrograms vaginal misoprostol in early pregnancy failure. Several additional and large randomized clinical studies are still required for most effective dose regimen of misoprostol for medical management of $1^{\text {st }}$ trimester missed abortions.

\section{CONCLUSION}

The use of misoprostol for medical management of $1^{\text {st }}$ trimester missed/anembryonic abortion is an effective, cheap, safe and convenient alternative to surgical evacuation. It is also concluded that 800 micrograms vaginal misoprostol is more effective than 600 micrograms vaginal misoprostol. But 800 micrograms misoprostol has more side effects than 600 micrograms misoprostol.

\section{Funding: No funding sources}

Conflict of interest: None declared

Ethical approval: The study was approved by the Institutional Ethics Committee

\section{REFERENCES}

1. Warburton D, Fraser FC. Spontaneous abortion risks in man: data from reproductive histories collected in a medical genetics' unit. Am J Hum Genet. 1964;16:125.

2. Pridjian G, Moawad A. Missed abortion: still appropriate terminology. Am J Obstet Gynecol. 1989;161:261-2.

3. Hertig AT, Livingstone RG. Spontaneous, threatened and habitual abortion: their pathogenesis and treatment. N Engl J Med. 1944;26:797-806.

4. Hughes J, Ryan M, Hinshaw K, Henshaw R, Ripsin $\mathrm{R}$, Templeton A. The costs of treating miscarriage: A comparison of medical and surgical management. $\mathrm{Br}$ J Obstet Gynaecol. 1996;103:1217-21.

5. Couzinet B, Le strat N, Ulman A, Baulieu EE, Schaison G. Termination of early pregnancy by the progesterone antagonist RU486 (mifepristone). N Engl J Med. 1986;315(25):1565-70.

6. Norman JE, Thong KJ, Baird DT. Uterine contractility and induction of abortion in early pregnancy by misoprostol and mifepristone. Lancet. 1991;338:1233-6.

7. Barbosa RM, Arilha M. The Brazilian experience with cytotec studies in family planning. Stud Fam Plann 1993 24(4):236-40.
8. Coelho HL, Teixeria AC, Santos AP, Forte EB, Morais SM, La Vecchia C et al. Misoprostol and illegal abortion in Fortaleza Brazil. Lancet. 1993;341(8855):1261-3.

9. El Rafaey H, Calder L, Wheatley DN, Templeton A. Cervical priming with prostaglandin E1 analogues, misoprostol and gemeprost. Lancet. 1994;343:12079.

10. National institute for Health and Care Excellence guidelines. Ectopic pregnancy and miscarriage: diagnosis and initial management. 2012.

11. Prasartsakulchai C, Tannirandorn Y. A comparison of vaginal misoprostol 800 microg versus 400 microg in early pregnancy failure: a randomized controlled trial. J Med Assoc Thai. 2004;87:S18-23.

12. Seervi N, Hooja N, Rajoria L, Verma A, Malviya K, Mehta N. comparison of different regimens of misoprostol for the termination of early pregnancy failure. Med J Armed Forces India. 2014;70(4):360-3.

13. Srikhao N, Tannirandorn Y. A comparison of vaginal misoprostol 800 microg versus 400 microg for anembryonic pregnancy: a randomized control trial. J Med Assoc Thai. 2005;88(2):S41-7.

14. Hooja N, Servi N, Mital P. Efficacy of vaginal Misoprostol in termination of early pregnancy failure. Sch Acad J Biosci. 2014;2(9):570-2.

15. Anita S, Anand S. A study of vaginal misoprostol for medical management of missed abortion upto 12 weeks of gestation. IOSR-JDMS. 2016;15(4):7:83-6.

16. Barcelo F, De Paco C, Lopez-Epsin JJ, Silva Y, Abad L, Parilla JJ. The management of missed miscarriage in an outpatient setting: 800 versus $600 \mathrm{mcg}$ of vaginal misoprostol. Aust N Z J Obstet Gynaecol. 2012;52(1):39-43.

17. Kovakisarach E, Jamnasiri C. Intravaginal misoprostol $600 \mu \mathrm{g}$ and $800 \mu \mathrm{g}$ for the treatment of early pregnancy failure. Int $\mathbf{J}$ of Gynecol and Obst. 2005;90(3):208-12.

18. Aryes de Campos D, Teixeira-da-Silva J, Campos I, Patricio B. Vaginal misoprostol in the management of first trimester missed abortions. Int $\mathrm{J}$ Gynaecol Obstet. 2000;71(1):53-7.

19. Thakur S, Pratap C. Comparison between sublingual 600 and 800 micrograms misoprostol after mifepristone for MTP up to 9 weeks gestation. Int $\mathbf{J}$ Reproduct Contracep Obstetr Gynecol. 2018;7(12):4996-5004.

Cite this article as: Khajuria R, Suri A, Jaggi R. Comparison of efficacy of 600 and 800 micrograms vaginal misoprostol in early pregnancy failure in SMGS: a tertiary health care hospital in Jammu, India. Int J Reprod Contracept Obstet Gynecol 2022;11:352-6. 